\title{
An Examination of the Impact of Public Spending on Poverty Reduction in Nigeria
}

\author{
Dr. Abdulhadi Ibrahim ${ }^{1} \&$ Salisu Umar ${ }^{2}$ \\ ${ }^{1}$ Department of Economics, Umar Suleiman College of Education, Gashua Yobe State Nigeria \\ ${ }^{2}$ Department of Economics, Aminu Saleh College of Education, Azare Bauchi State Nigeria
}

\begin{abstract}
The study investigates the impact of public spending on poverty reduction in Nigeria using time series data from 1980 2019.Vector Autoregressive (VAR) model has been used to achieve the objectives of this study. The cointegration test reveals there is long run relationship among the variables used in the study. The normalized cointegration result further reveals that government total expenditure has significant impact on poverty GDP and private investment have positive effects on poverty while inflation has negative impact on poverty. The study recommendations include the following among others: embezzlement of public funds and corruption should be tackled, GDP should be fairly distributed for it to have impact on poverty and measures should be put in place to curb inflationary pressure. Lastly unnecessary expenditures should be shortened and focus should be on expenditure that increases economic growth and reduces poverty.
\end{abstract}

Keywords: Public Spending, Poverty Reduction, Cointegration, VAR

\section{INTRODUCTION}

$\mathrm{P}$ overty has been a fundamental problem theoretically and empirically. Poverty in Nigeria is both rampant and long standing. Since 1996, the poverty incidence has never been below 40\% (National Bureau of Statistics, 2017). The impact government expenditure has on poverty reduction has been acknowledged from time immemorial. Government provided relief materials to the poor during the Roman Empire and Greek civilizations or what is called Antiquity. For many centuries till the beginning of the 16th Century the responsibility of poverty alleviation rested on the church and mosque mainly through charity. However, the church and the state during the times were inseparable. The modern forms of government expenditure and intervention in poverty alleviation date back to the poor relief organized by the state after the $16^{\text {th }}$ century. These gave way to early welfare schemes that were already in place by early 19th century and the social security schemes that guide poverty reduction today (Herman, 2004).

The reduction of poverty is the most difficult challenge facing any country in the developing world where on average majority of the population is considered poor. The description of Nigeria as a paradox by the World Bank (2012) has continued to be confirmed by events and official statistics in the country. The paradox is that the poverty level in Nigeria contradicts the country's immense wealth. Evidences in Nigeria show that the number of those in poverty has continued to increase. For example, the number of those in poverty increased from $28 \%$ in 1980 to $46 \%$ in 1985 , it declined slightly to $42 \%$ in 1992 but increased very sharply to $67 \%$ in 1996 . Since then the poverty incidence in Nigeria has never been below $40 \%$ (NBS, 2016).

In spite of the impressive economic growth over the years, unemployment and the incidence of poverty have worsened since 2004.The National Bureau of Statistics (NBS, 2017) recently released the poverty incidence figures for 2018 and 2019 for Nigeria. The figures suggest that the incidence of poverty in Nigeria worsened between 2015 and 2016 which led to the description of Nigeria as the world poverty capital.

To achieve the desired macroeconomic goals, public spending via fiscal policy has been found, and widely regarded as a potent measure for enhancing growth, income redistribution and poverty reduction particularly in developing nations (Falade E. O. and Babatunde D. 2020)

Another problem has been to channel public expenditure into those areas of the economy where its effects will be optimal in terms of growth, poverty reduction and distribution. With trillions of naira Nigeria spent to achieve economic growth and reduce poverty, then why are majority of Nigerians poor? Therefore, there is the need to examine whether or not public expenditures have any impact on poverty reduction in Nigeria.

However, substantial volumes of empirical research based on identifying the significance of public expenditure on economic growth have been conducted in Nigeria. To the best of my knowledge only a few studies focused on government expenditure and poverty reduction in Nigeria, e.g. Olofin (2010), and Stephen (2011), Enyim (2013), Oriavwote and Ukawe (2018). This study differs from the previous in two ways: firstly, the application of VAR model and secondly, the extension of time period to 2019. It is against this backdrop that this research work sets out to examine the impact of public spending on poverty reduction in Nigeria using time series data covering the period, 1980 to 2019.

The main objective of the study is to empirically assess the extent to which government expenditure impact on poverty reduction in Nigeria. The specific objectives of the study are:

i. To examine the long-run relationship between public spending and poverty reduction in Nigeria.

ii. To investigate how other variables like GDP, private investment and inflation influence poverty in Nigeria. 


\section{Hypotheses of the Study}

i. Ho: public spending has no impact on poverty in Nigeria

ii. Ho: GDP, private investment and inflation have no impact on poverty in Nigeria

\subsection{Government Expenditure Trends}

Figure 1 shows the composition and trends in government total, recurrent and capital expenditures for the periods 2009 to 2019. It also reveals the divergence and convergence of capital and recurrent expenditure in total government expenditure. Recurrent expenditure is much higher than the capital expenditure in all the periods. While recurrent expenditure exhibits rising trends, capital expenditure shows a declining and rising pattern over the periods. The total government expenditure growth and recurrent expenditure growth have revealed similar trends over the years

Figure 1: Trends in Government Spending for the Last Decade

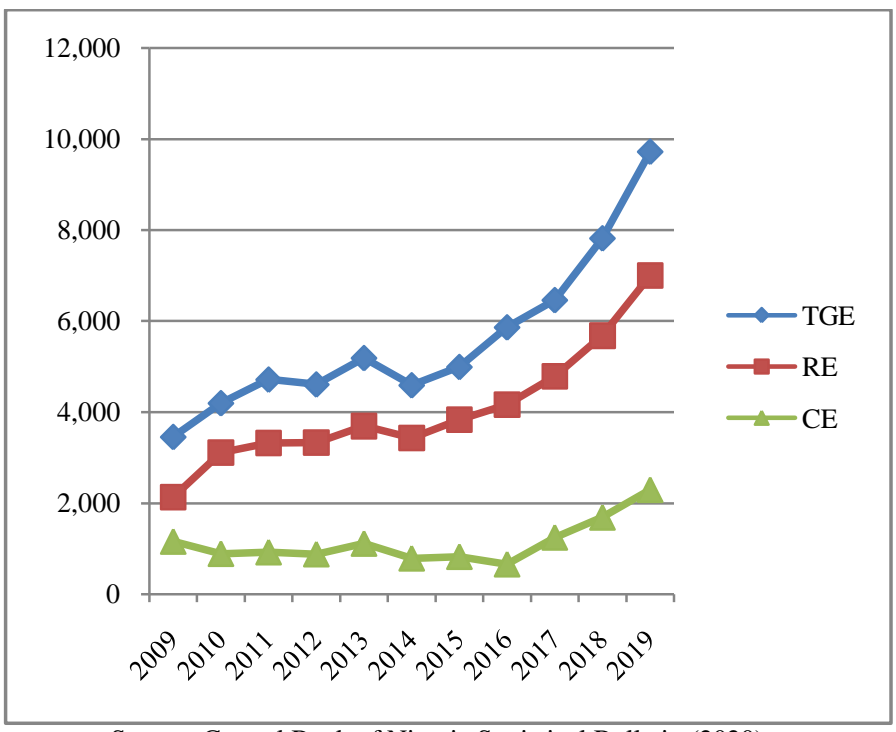

Source: Central Bank of Nigeria Statistical Bulletin (2020).

Where: TGE: Total Government Expenditure in Billions, RE: Recurrent Expenditure in Billions and CE: Capital Expenditure in Billions

Figure 2: Nigeria Poverty Profile

Poverty Propile of Nigeria from 2009 to 2019

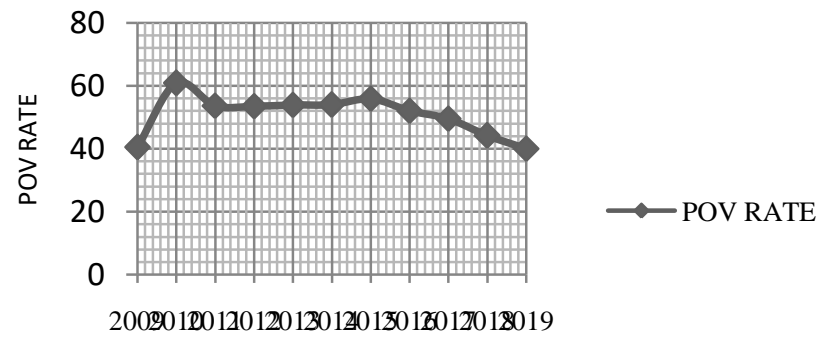

Year

\section{LITERATURE REVIEW}

\subsection{Concept of Poverty and Measurement}

A concise and universally accepted definition of poverty is elusive largely because it affects many aspects of the human condition, including the physical, the moral and the psychological. At the same time, there is always the difficulty in deciding where to draw the line between the "poor" and the "non poor". According to World Bank Report (2002), poverty is the inability to attain a minimum standard of living measured in terms of consumption needs. The report constructed some indices based on a minimum level of consumption in order to show the practical aspect of poverty. These include lack of access to resources, lack of education and skills, poor health, malnutrition, lack of political freedom and voice, lack of shelter, poor access to water and sanitation, vulnerability to shocks, violence and crime, political discrimination and marginalization. Similarly, the United Nations Human Development (UNHD) has introduced the use of such other indices as life expectancy, the infant mortality rate, the primary school enrolment ratio and number of persons per physician to measure poverty in a country (UNDP, 2010).

\subsubsection{Measurement of Poverty}

The Head Count Index

$$
\mathrm{p}_{0}=\frac{1}{\mathrm{n}} \sum_{\mathrm{i}=1}^{\mathrm{q}}\left(1-\frac{\mathrm{y}_{\mathrm{i}}}{\mathrm{z}}\right)^{0}=\frac{1}{\mathrm{n}} \mathrm{q}=\frac{\mathrm{q}}{\mathrm{n}}=\mathrm{H}
$$

The head count index measures the proportion of the population falling below the poverty line. This ratio, according to Kimalu et al., (2002), however, has some shortcomings. First, it does not show how far below the poverty line the poor are; that is, it ignores the inequality among the poor. Second, it forces the overall poverty index to remain constant even when the welfare of the poor has improved or worsened. Third, with this index, an income transfer from an extremely poor person to a person just below the poverty line (enabling them to cross the line) would show a reduction in poverty despite the decline in the income of the extremely poor.

\section{The Poverty Gap Index}

P1 is an index that measures the extent to which the incomes of the poor lie below the poverty line. It measures the intensity of poverty by averaging the distance between the expenditure of the poor persons and the poverty line. According to Kimalu et al., (2002), since the index measures the shortfall of the average income of the poor relative to the poverty line, it can be used to estimate the resources that would bring the expenditure of every poor person up to the poverty line thereby eliminating absolute poverty.

The index is calculated using the formula:

$$
\mathrm{p}_{1}=\frac{1}{\mathrm{n}} \sum_{\mathrm{i}=1}^{\mathrm{q}}\left(1-\frac{\mathrm{y}_{\mathrm{i}}}{\mathrm{z}}\right)^{1}
$$


Although superior to $\mathrm{P}_{0}, \mathrm{P}_{1}$ still implies uniform concern about theor lead more productive lives, increasing the return on depth of poverty, in that it weights the various income gaps of thevestments.

poor equally (Aigbokhan, 2000). The major weakness of the poverty

gap index is therefore that it does not differentiate the degree of inequality among the poor when it is used to assess welfare (Kimgrowth and poverty in Nigeria. The study employs et al., 2002).

econometric method, Ordinary Least Square multiple regression (OLS), to determine the relationship. The time Poverty Severity Index series secondary data were screened using stationarity and co integration tests. The data were found to be stationary and co$\mathrm{P} 2$ is an index that shows the severity of poverty by squaring the gap grated. The empirical findings demonstrated a significant between the expenditure of the poor individual and the poverty line and direct relationship between economic growth and poverty Because the index gives more weight to the poverty of the poorest, in Nigeria. This implies that the economic growth rate does measures the degree of inequality among the poor implying that treduce poverty in Nigeria. In other words, the impressive transferring income to the poorest from the better-off poor should rowth of the economy in recent times could not yield an lower the poverty index (Kimalu et al,2002).

$$
\text { improvement in living standard of the people. }
$$

It increases more than proportionately with the poverty gap. The (2013) carried out a study on the causality between larger the poverty severity index as measured by $\mathrm{P}_{\alpha}=2$, the greater tnancial deepening, economic growth and poverty in Nigeria, the poverty gap, which, indicates that poverty is severest among the ing annual time series covering the 1960 to 2011 period. very poor (Kimalu et al., 2002).

The index can be calculated using the formula:

$$
\mathrm{p}_{2}=\frac{1}{\mathrm{n}} \sum_{\mathrm{i}=1}^{\mathrm{q}}\left(1-\frac{\mathrm{y}_{\mathrm{i}}}{\mathrm{z}}\right)^{2}
$$

\subsection{Empirical Literature}

Some recent studies have estimated the effect of public expenditure, including public investment expenditure on poverty. For instance, Olofin (2010) examines the relationship between the components of defense spending and poverty reduction in Nigeria for the period 1990-2010. He estimated four models using Dynamic Ordinary Least Square (DOLS) method, two in which poverty index constructed from human development indicators serves as dependent variable and the others in which the infant mortality rate serves as the dependent variable. The results reveal that military expenditure per soldier, the military participation rate, trade, population and output per capita square were positively related to the poverty indicator. They were all found to be statistically significant except trade and output per capita square. Population that was not significant in the model. Military expenditure, secondary school enrolment and output per capita were negatively related to the poverty level. However, only total military expenditure was found to be statistically significant in model one and three, while output per capita in model three was found to be statistically significant. Others were statistically insignificant. The findings confirm the tradeoff between the well-being and capital intensiveness of the military in Nigeria, pointing to the vulnerability of the poor among Nigerians.

Shahid (2010) examined the effects of various categories of government expenditure on poverty in Pakistan, using the autoregressive distributed lag model over the period 19722008. The empirical studies have shown that investment in social services improves human capital and reduces poverty over the long run. Good education and health care help the The Johansen cointegration test is used to examine the longrun relationship between finance, growth and poverty. The short and long run causality between these variables is tested, using a modified Hsaio-Granger causality within a Vector Autoregressive (VAR) and Vector Error Correction Model (VECM) framework. The results indicate no evidence of long run equilibrium relationship between finance, economic growth and poverty. Further, the results show a short-run unidirectional causality from growth to poverty conditional on finance.

Enyim (2013) conducted a study on Government Spending and Poverty Reduction in Nigeria's Economic Growth. The research work employed the multiple regression model based on Ordinary Least Square (OLS). The regression result shows that public spending has a significant impact on poverty reduction in Nigeria. It is estimated from the result that a 1\% increase in the Agricultural Credit Guarantee Scheme Fund (AGCSF) will, on the average lead to decrease by $0.06 \%$ in the Poverty Level. The study also found a positive relationship between government spending and poverty.

Ukpong et al (2013) undertook study of cointegration inference on the issues of poverty and population growth in Nigeria. The Augmented Dickey-Fuller tests as well as the Engle Granger and Johansen's cointegration tests were used to test for cointegration and stationarity of the time series data on the poverty rate, population growth and the gross domestic product (GDP) real growth rate in Nigeria, while the ordinary least squares (OLS) regression analysis was used to estimate a statistical model for their relationship. The results show that the variables are trend stationary and cointegrated; with a positive relationship between the poverty rate and population growth, and a negative relationship between the GDP real growth rate and the poverty rate in Nigeria.

Ebere and Osundina (2014) investigated the impact of disaggregated expenditure on infrastructure on poverty reduction. The Vector Autoregressive Model was adopted. The result showed a long run relationship between government expenditure on infrastructure and poverty 
reduction in Nigeria. The result indicated further that government expenditure on building and construction has a positive and significant impact on poverty reduction. Government expenditure on health has an insignificant and negative impact on poverty reduction.

Oriavwote and Ukawe (2018) conducted a study on government and poverty reduction in Nigeria covering the periods 1980 to 2016. The estimated parsimonious ECM shows that though government expenditure, with one period lag, on health has a significant positive on the per capita income, it has a low elasticity. The result indicates further that government expenditure on education has a significant and positive impact on the per capita income. Further, the result reveals that government expenditure on building and construction has positive significant impact on the per capita income, the elasticity is however very low.

Nwadike et al (2020), conducted a study on inflation and poverty reduction in Nigeria for the period 2000 to 2018 using granger causality approach. Findings of the study show a decreasing inflation will decrease poverty level while a rising inflation will increase poverty level in Nigeria.

The empirical studies on public spending and poverty are mostly from countries outside Africa and a few from African countries. While most empirical studies in Nigeria focus mostly on public spending and economic growth; economic growth and poverty; the literacy rate and poverty; MDGs expenditure and poverty; poverty and population growth; youth unemployment and poverty; military spending and poverty reduction; e.t.c. To the best my knowledge, only a few studies have attempted to empirically examine the impact public spending at aggregative level on poverty using time series data in Nigeria. Therefore, this research work sets out to fill this gap.

\section{METHODOLOGY}

Although some studies on poverty have considered poverty as a qualitative variable in recent years, data availability has permitted alternative approaches, including time series analysis, analysis at the single-country level. Therefore, this study follows Ukpong et al (2013), Eyim B O (2013), Ijaiya T G (2000), and Osinibi (2005) time series studies on poverty that used the Nigerian annual poverty incidence (rate), as measured by NBS using relative poverty measure.

This study employed annual data frequency on the variables, namely poverty, government expenditure, GDP, private investment and inflation from1980 to 2019 for its empirical analysis.

\section{Model Specification}

The model specification for this study was designed in the following option.

Pov $=\mathrm{f}(\mathrm{GE}, \mathrm{GDP}, \mathrm{PINV}, \mathrm{INF})$

Where:
Pov $=$ Poverty Rate (Poverty head count ratio, Head count ratio of Poverty is used here. $\mathrm{P}=\mathrm{Q} / \mathrm{N}$ where $\mathrm{Q}=$ no of poor and $\mathrm{N}$ denotes the total population.

$\mathrm{GE}=$ Total Government Expenditure (Both Capital and Recurrent as a percentage of GPD)

GDP $=$ Gross Domestic Product

PINV= Private Investment as a Percentage of GDP

$\mathrm{INF}=$ Rate of Inflation

In econometric form:

$P O V=\beta_{O}+\beta_{1} \log G E+\beta_{2} \log G D P+\beta_{3} \log P I N V+$ $\beta_{4} I N F+\mu \ldots \ldots \ldots \ldots \ldots . .(2)$

From the model, a priori expectation may be mathematically denoted as:

$\beta_{1}<0, \beta_{2}<0, \beta_{3}<0, \beta_{4}>0$.

\section{Unit Root Test}

The study employed the commonly used augmented DickeyFuller (ADF) and Phillips-Perron (PP) unit root tests to determine the variables' stationarity properties or integration order. Before estimating the VAR model, we use the most recommended Akaike information criterion (AIC) test to determine the lag length of the VAR system to make sure the model is well specified.

The Vector Autoregressive (Var) Model

A generalized form of vector auto regression is stated as

$\mathrm{Y}_{t}=\mu+\sum_{k=1}^{p} \Pi_{k} \mathrm{Y}_{t-1}+\varepsilon_{t}$

Where $\mu$ is a vector of constant and $\varepsilon_{\mathrm{t}}$ is a g-vector of white noise residuals at time $\mathrm{t}$ with zero mean and constant variance. For this study, the regression model has $\mathrm{n}=5$ variables with four independent and one dependent variable.

\section{RESULTS AND DISCUSSION}

Table 4.1 Unit Root Test Results

\begin{tabular}{|c|c|c|c|c|}
\hline & \multicolumn{2}{|c|}{ ADF Unit Root } & \multicolumn{2}{c|}{ PP Unit Root } \\
\hline Variables & T Statistic & Probability & T Statistic & Probability \\
\hline POV & $-2.756545 * * *$ & 0.0809 & $-2.736512 * * *$ & 0.0840 \\
\hline LGE & $-6.339193 *$ & 0.0000 & $-27.7109 *$ & 0.0001 \\
\hline LGDP & $-4.682436 *$ & 0.0008 & $-4.682436 *$ & 0.0008 \\
\hline LPINV & $-4.584464 *$ & 0.0011 & $-5.216048 *$ & 0.0002 \\
\hline INF & $-5.152482 *$ & 0.0002 & $-9.907282 *$ & 0.0000 \\
\hline
\end{tabular}

Source: Researcher's computation using E-views 10.

Note: $*$ and $* * *$ show stationary at $1 \%$ and $10 \%$ level of significant

Table 4.1 presents the unit root test conducted for the variables used in the study. The results show the variables are non Stationary at level, but are Stationary at fist difference, 
once the series are stationary by using first difference, they can be used in regression analysis by applying the cointegration technique, which shows the long run relationship among the variables.

Table 4.2 Lag Length Selection VAR Estimates

\begin{tabular}{|c|c|c|c|c|c|c|}
\hline $\begin{array}{c}\text { Lag } \\
\text { length } \\
\text { selecti } \\
\text { on } \\
\text { criteria }\end{array}$ & LOGL & LR & FPE & AIC & SC & HQ \\
\hline $\begin{array}{c}\text { lag 1 } \\
\text { values }\end{array}$ & $\begin{array}{c}158.08 \\
6\end{array}$ & $\begin{array}{c}150.3149 \\
*\end{array}$ & $\begin{array}{c}19.6897 \\
8 *\end{array}$ & $\begin{array}{c}17.0986 \\
8 *\end{array}$ & $\begin{array}{c}18.5864 \\
6 *\end{array}$ & $\begin{array}{c}17.4491 \\
6 *\end{array}$ \\
\hline
\end{tabular}

Source: Researchers computation, E-views 10

*indicates lag order selected by the criterion

Table 4.2 establishes a relationship between the variables based on the LR statistics, the Final prediction error, the Akaike information criteria, the Schwarz information criteria and the Hannan-Quinn information criteria and also prefers lag one as the optimal lag length.

Table 4.3 The Juhansen-Julius cointegration Based on Trace Statistic

\begin{tabular}{|c|c|c|c|c|}
\hline Hypothesized & & Trace & 0.05 & \\
\hline No. of $\mathrm{CE}(\mathrm{s})$ & Eigenvalue & Statistic & $\begin{array}{c}\text { Critical } \\
\text { Value }\end{array}$ & Prob.** \\
\hline None * & 0.932215 & 103.7820 & 69.81889 & 0.0000 \\
\hline At most 1 & 0.567318 & 47.26222 & 47.85613 & 0.0568 \\
\hline At most 2 & 0.542199 & 29.66941 & 29.79707 & 0.0517 \\
\hline At most 3 & 0.465785 & 13.26169 & 15.49471 & 0.1056 \\
\hline At most 4 & 0.004542 & 0.095607 & 3.841466 & 0.7572 \\
\hline \multicolumn{5}{|c|}{ Trace test indicates 1 cointegrating eqn(s) at the 0.05 level } \\
\hline \multicolumn{5}{|c|}{$*$ denotes rejection of the hypothesis at the 0.05 level } \\
\hline \multicolumn{5}{|c|}{$\begin{array}{l}\text { **MacKinnon-Haug-Michelis (1999) p-values } \\
\text { Source: Researcher's computation using E-views } 10 . \\
\text { Table 4.4 The Juhansen-Julius cointegration Based on Max. Eagen Value } \\
\text { Statistic }\end{array}$} \\
\hline Hypothesized & & Max-Eigen & 0.05 & \\
\hline No. of $\mathrm{CE}(\mathrm{s})$ & Eigenvalue & Statistic & $\begin{array}{c}\text { Critical } \\
\text { Value }\end{array}$ & Prob.** \\
\hline None * & 0.929213 & 58.25786 & 33.87687 & 0.0000 \\
\hline At most 1 & 0.707915 & 27.07560 & 27.58434 & 0.0580 \\
\hline At most 2 & 0.568276 & 18.47933 & 21.13162 & 0.1129 \\
\hline At most 3 & 0.350688 & 9.500525 & 14.26460 & 0.2468 \\
\hline At most 4 & 0.004900 & 0.108076 & 3.841466 & 0.7423 \\
\hline \multicolumn{5}{|c|}{ Max-eigenvalue test indicates 1 cointegrating eqn(s) at the 0.05 level } \\
\hline \multicolumn{5}{|c|}{ * denotes rejection of the hypothesis at the 0.05 level } \\
\hline \multicolumn{4}{|c|}{$\begin{array}{l}\text { **MacKinnon-Haug-Michelis (1999) p-values } \\
\text { Source: Researcher's computation using E-views } 10 .\end{array}$} & \\
\hline
\end{tabular}

Tables 4.3 and 4.4 show the number of cointegrating equations. The tables show that there is only one cointegration at the 5\% level at a none hypothesized cointegrating equation, meaning that the johansen procedure using the trace test and maximum Eigen value statistics indicates only one cointegration, which is found by comparing the trace test statistics and its critical value at 0.05 . If the trace test is higher than the critical value, it means that there is the presence of cointegration. Similarly the maximum Eigen value test is greater than the critical values. It means there is no cointegration. In this case, the trace statistics of 103.87 is higher than the critical value of 69.81, indicating cointegration. So also the maximum Eigen value 58.25 is higher than 33.87, indicating one cointegrating relation.

\section{The Vector Error Correction Result}

The Vector error correction technique has been employed to ascertain the short-run effects or dynamics of the variables. This is because it has been observed that while some variables may have long run effects on other variables they may also have a short run effect with different effects.

Table 4.5 Cointegration equation normalized with respect to POV Model B

\begin{tabular}{|c|c|c|c|c|}
\hline POV & LGE & LGDP & LPINV & INF \\
\hline 1.000000 & 75.63495 & -68.00607 & -6.25487 & -0.336362 \\
\hline & $(6.35786)$ & $(5.02289)$ & $(2.44636)$ & $(0.10173)$ \\
\hline
\end{tabular}

Source: Researcher's computation using E-views 7.1

Table 4.5 presents coingration equation with respect to POV. It can be seen that all the variables with the exclusion of government expenditure have incorrect signs. The sign borne by the parameter estimate of GE conforms to a priori expectation. There existed a negative relationship between the poverty level and Government expenditure. This explains that an increase in government expenditure reduces poverty. That is, a unit increase in government expenditure will reduce poverty by $75 \%$. The result shows a positive relationship between poverty and gross domestic product. An increase in GDP is expected to reduce poverty but the empirical result shows the impressive growth of GDP in Nigeria has not reduced poverty during the period under review. This may be attributed to unequal distribution of GDP between the rich and the poor. The positive sign of the coefficient of private investment does not agree with a priori expectation, meaning poverty increases despite increase in private investment. Lack of steady power supply, good roads and other basic infrastructures that government failed to provide, may have undermined the potentials and effective performance of the private sector. The fact that its coefficient is statistically significant has the great potential to reduce poverty. The positive relationship between poverty and inflation implies that inflation contributes to poverty level in Nigeria.

\section{CONCLUSION AND RECOMMENDATIONS}

There can be no meaningful poverty reduction without adequate spending by the government. Poverty reduces due to increase in public spending. Government expenditures stimulate the economy in long run through increase in aggregate demand. Our results suggested that there exists a long run relationship among variables. This result conforms to our a priori expectation. It means government expenditure 
plays a significant role in poverty reduction. In simple terms government expenditure on the aggregate reduces poverty while the impressive growth of GDP does not trickle down to the poor. The positive coefficient of PINV implies that private investment is not significant in terms of poverty reduction. The fact that its coefficient is statistically significant has the great potentials to reduce poverty if the enabling environment is provided by the government. Inflation has a negative relationship with poverty. This implies inflation contributes to poverty level in Nigeria.

Guided by the findings of the research, the following recommendations have been suggested.

Firstly, it is suggested that any poverty reduction programmes by the government must be given adequate and sustained funding to create the necessary conducive atmosphere for effective implementation. Public spending must be specified as a percentage of the national budget and should not be interfered with, no matter who assumes the mantle of leadership of the country. Secondly, private investment should be directed towards employment generation and increasing productivity. Enabling environment should be provided to private sectors, if they are to reduce poverty. Thirdly, government should ensure that the GDP is fairly distributed to bridge the wide gap that exists between the few rich and the majority poor. This can be achieved through taxes and use the fund to provide economic and social infrastructures in the country. Fourthly, strong monetary and fiscal measures should be put in place to check the inflation and minimize its effect on the poor.

\section{REFERENCES}

[1] Aigbokhan, B.E. (2008),Poverty, growth andiInequality in Nigeria: A case study. African Economic Research Consortium (AERC). Nairobi, Kenya.

[2] Aye C G (2013), Causality between financial depending, economic growth and poverty in Nigeria. The business and Management Review, volume 3.

[3] Bello and Roslan A (2010) Has poverty reduced in Nigeria 20 years after? European Journal of Social Science. Vol 15. No 1.

[4] Central Bank of Nigeria (1998). Measuring and Monitoring Poverty in Nigeria: Proceedings of the Seventh Annual Conference of the Zonal Research Units. Abuja: CBN Research Dept., 319p.

[5] Central Bank of Nigeria, Research Department (1999) Nigeria's development Prospects: Poverty Assessment and Alleviation Study (Abuja: CBN).

[6] CBN, (2019) Annual Report, 31st December 2019.

[7] CBN, (2019) Statistical Bulletin.

[8] CBN, (2020) Statistical Bulletin.

[9] Creedy, J. (1996) Fiscal Policy and Social Welfare: An Analysis of Alternative Tax and Transfer systems. Edward Edgar.

[10] Falade E. O. and Babatunde D. (2020) Functional government spending, unemployment and poverty reduction in Nigeria. Journal of Economics and Development Stuidies. Vol 8 No 1 ISSN: 2334-2390.
[11] Ebere, C., \& Osundina, O. A. (2014) Disaggregated government spending on infrastructure and poverty reduction in Nigeria. Global Journal of Social Sciences and Economics, 14(5).

[12] Enyim B O (2013) Government spending and poverty reduction in Nigeria's economic growth. International Journal of Social Science and Humanities, Vol. 4

[13] Granger, C. W. J. and Newbold, P. (1974) "spurious regression in Econometric".

[14] Herman (2004) poverty and government expenditure: An assessment of influence of government and interventions on poor groups with focus on Rwanda. Doctor of. Phil. thesis institute of social development, University of Western Cape.

[15] Ijaiya T. G. (2000) Inflation and poverty in Nigeria. International Journal of Business and Social Science. Vol 7 No 1.

[16] Johansen, S. (1982),"Statistical Analysis of Cointegration Vectors," Journal of Economic Dynamics and control, 12: 231254.

[17] Musgrave, R.A. (1956). The Theory of Public Finance: A study in Public Economy.

[18] NBS (2012), National Bureau of Statistics Data Base.

[19] NBS (2016), National Bureau of Statistics, Poverty Profile for Nigeria (March) [Brochure]. NES: 48-61.

[20] Nigeria Poverty Profile 2010.

[21] Nwadike E. C., Njoku C. O. and Badmus S. O. (2020), Inflation and poverty in Nigeria: A granger causality approach. International Journal of Business and Management Technology Vol. 4 Issue 3 May-June 2020 ISSN: 2581-3889.

[22] Olofin A (2010) Defense spending and poverty reduction in Nigeria. American Journal of Economics.

[23] Olukayode M. E. (2009) Does government speeding spur economic growth? MPRA Paper No. 17941.

[24] Oriavwote E. V and Ukawe A. (2018) Government expenditure and poverty reduction in Nigeria. Journal of Economics and Public Finance Vol 4 No. 22018

[25] Osinubi S T (2005) Macroeconometric analysis of growth, unemployment and poverty in Nigeria. Pakistan Economic and Social Review Vol. XLIII, No 2.pp 249-269.

[26] Psacharopulos, G. (1993) A Political Economy of Poverty, Growth and Equity. A Comparative Study. World Bank.

[27] Selowsky, M. (1979). Who benefits from Government Expenditure? Oxford University, London.

[28] Shahid A (2010) Does the Choice of Government Expenditure Affect Poverty? Time Series Evidence from Pakistan. International Conference on Applied Economics.

[29] Spicker, P. (1993). Principles of social welfare. Routledge.New York and London.

[30] Stephen A B (2011) A critical appraisal of the linkage between literacy rate and the incidence of poverty in Nigeria. Journal of Emerging Trends in Education Research and Policy Studies.

[31] Tilak, J.B.G. (1989). Education and its relation to economic growth, poverty and income distribution: past evidence and further analysis. World Bank Discussion Paper.

[32] Ukpong G I, Ekpebu D and Ofem N (2013) Cointegration inferences on issues of poverty and population growth in Nigeria. Journal of Development and Agricultural Economics. Vol. 5(7) pp.277-283.

[33] UNDP (2010). Human Development Report Nigeria 2008-2009. Achieving Growth with Equity. 2010.United Nations Development Programme.UNDP, New York. Retrieved from http://hdr.undp.org/ (Accessed on $25^{\text {th }}$ February,2013)

[34] World Bank (2012). Poverty Profile for Nigeria: 1985-2011. Washington, DC: World Bank.

[35] Yusuf M, Malarvizhi C. A. and Khin A. A.(2013) Trade liberalization, economic growth and poverty reduction in Nigeria. International Journal of Business and Management. Vol 8 NO12. 